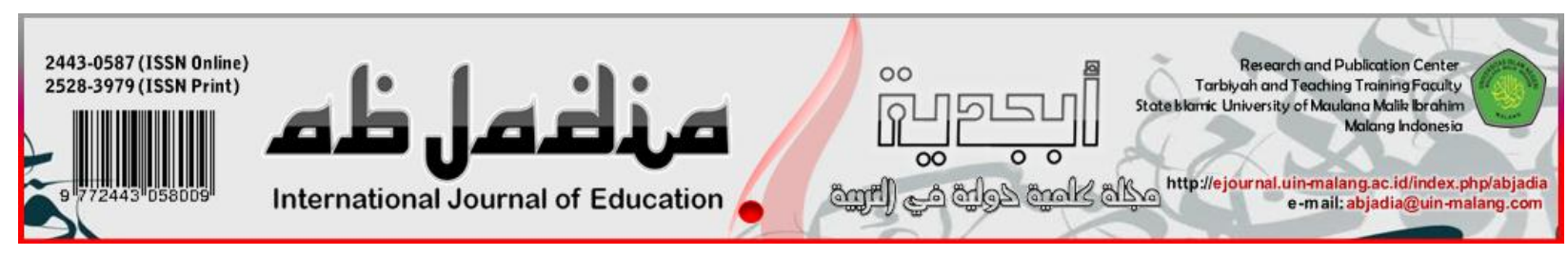

\title{
INTEGRATING THE PROGRAM OF SCHOOL CURRICULUM AND PESANTREN EDUCATION; CASE STUDY ON THE PESANTREN LOCATED IN THE MADRASAH AT MALANG CITY
}

\author{
Nur Ali \\ Universitas Islam Negeri Maulana Malik Ibrahim Malang, Indonesia
}

Article History:
Received : 06-06-2020
Revised : 12-06-2020
Accepted : 14-06-2020
Published : 30-06-2020

Keywords:

Integrated Curriculum Program,

Literacy, Ma'had, Madrasa, Taklim

Ma'hady, Taklim Madrasy

*Correspondence Address:

nurali@uin-malang.ac.id

\begin{abstract}
As a modern Islamic educational institution, Madrasa (Islamic boarding school) has shifted into a public school that has Islamic identity and the issue of restructuring its curriculum is assumed as a deteriorating factor in religious aspects for its graduates. Related to this, Madrasa have responded by carrying out a curriculum program development through the integration of Madrasa curriculum program and Ma'had education (Islamic dormitory). This article aims to describe the background of the integration of Madrasa curriculum program and the education in Ma'had as well as the activities and literacy that determine the success of the curriculum program integration. The data obtained from the observation, interview, and documentation were then analyzed through reduction, display, and verification phases. Afterward, the data triangulation was also conducted. It led to several findings. First, the integrated curriculum program was carried out based on the vision and mission of both Madrasa and Ma'had, and the advance of religious study and science. Second, taklim madrasy and taklim Ma'hady (learning activity conducted in Madrasa and Ma'had) have become the determining factors for the successful implementation of the integrated curriculum program. Moreover, all guests ranging from the officials of the Ministry of Religious Affairs, visitors from other cities and overseas, the Madrasa committee, and all tutors in the Madrasa have also affected the information literacy, digital, and collaboration levels. This sudy provides suggestions to conduct the integration of the school, Madrasa curriculum program and Ma'had program in one location to develop the students' religious behavior, tolerance, empathy, spirituality knowledge, and literacy skill.
\end{abstract}

\section{(C) Introduction}

As an Islamic educational institution that provides education about Islamic values as written in the Quran and kitab kuning (pre-modern book on Islam), pesantren (Islamic boarding school) has lost its identity as an Indonesian institution of indigenous education. It is the same case for Madrasa that is renowned as a formal institution of Islamic education. The public assumes that its identity has changed since it emphasized more on the accomplishment of the general curriculum, but focused less on the Islamic studies curriculum. It is in line with the finding that several learning activities 
conducted in a pesantren and modern Islamic educational institution amplify the focus on science subject (Dahlan, 2016; Yusuf, 2017).

Madrasa and pesantren have given their response regarding the judgment towards their curriculum activities and the learning program. Madrasa and Ma'had/pesantren run various activities and integrated learning programs through Ma'had and Madrasa's integrated curriculum program, general and Islamic studies curriculum, intracurricular and extracurricular activities, and self-development activities. It is completely in accord with the goals of national education that is "to provide a chance for Indonesian citizens to develop their full potential for acquiring spiritual and religious strengths, develop self-control, personality, intelligence, morals, and noble character, skills and responsibility that one needs for him/herself, for the community, for the nation, and for the State" (Act of the Republic of Indonesia on National Education System Number 20, 2003). Hence, the educational institution needs to be designed to create an educational process and learning atmosphere to develop students' potentials in active, innovative, and creative manners to obtain skills, noble characters, personalities, insight, and spiritual strengths that the student and the society need.

The existing literature that discussed pesantren and Madrasa only focused on three aspects. First, there was a study that told about the factor that inspires the establishment of pesantren education and connected it to the pesantren curriculum pesantren (Abdullah, 2013; Fauzan \& Fata, 2019; Saifuddin, 2015). Another factor the study told was related to the history of Madrasa curriculum and the percentage of general and Islamic studies curriculum conveyed in certain subjects in Madrasa education (Abdullah, 2013; Fakhruddin \& Saepudin, 2018; Hasri, 2014; Nasir, 2015; Saifuddin, 2015). Second, it was a study on the competency of the Madrasa and pesantren's graduates and the solutions given (Fauzan \& Fata, 2019; Mukhibat, 2016; Rohmah \& Arifin, 2017; Styaningsih, 2016). Third, it was a study that investigated the effects of the establishment of formal schools around the pesantren environment and its (Ali, 2019b; Fauzan \& Fata, 2019; Jamasri, 2018; Karimah, 2018; Kemenag, 2019).

The emphasis on those three studies has not laid its focus on a critical analysis concerning any reason why the formal educational institution integrated Islamic activities and the school curriculum as well as integrated the Ma'had educational program and the school curriculum program. Simultaneously, there is no review concerning the potential of integrated activity of Madrasa curriculum program and Ma'had educational program.

This writing is written as a response to the lack of discussion on the Madrasa and pesantren education potential in implementing the integration of the two. Madrasa and Ma'had possess a big strength and opportunity to develop an integrative program to 
create graduates who master the ability in science, technology, art, and have strong piety and faith. Following this matter, two questions are then formulated, (1) what are the underlying factors that initiate the integrative activities of the Madrasa curriculum and education of Ma'had al-madani MTsN I (Islamic Junior High School), and (2) how do the activity and literacy factors determine the success of the integrated program of Madrasa curriculum and the education of Ma'had al-madani in MTsN 1 Malang implementation. These two questions are expected to provide a solution for the dynamic integration of Madrasa curriculum and Ma'had education.

This writing is organized based on three arguments. First, as an educational institution under the auspices of the Ministry of Religious Affairs, Madrasa has the responsibility to implement religion and science in the curriculum (Ministry of Religious Affairs, 2019). Moreover, seen as a public school that has Islamic characteristics, Madrasa has the potential to integrate curriculum programs and pesantren education. Second, Indonesian society still believes in Madrasa as the dormitory-based Islamic educational institution in Indonesia that can shape students' noble characteristics and deep spirituality. In the dormitory of the pesantren's environment, the students are educated and accustomed to live independently, help each other for good deeds, and share any information about learning sources. Third, the dormitory system enables students to use one's strength to help others who have weaknesses, in mutual manners regardless of any differences and similarities among them. Those differences and similarities may shape tolerance and empathy. However, the Madrasa curriculum program does not have the ability to integrate religion and science in school classrooms. In other words, because the curriculum in effect in Madrassas must follow established guidelines, integrating the program of school curriculum with pesantren in one location with schools has the potential to carry out integration programs for giving birth to graduates who have the breadth of knowledge, and the greatness of morals.

\section{[Deoretical Support}

Curriculum development is the process of planning, implementing, and evaluating the learning opportunity to make changes demanded by students. The policy was issued by the government through a Joint Decree of three ministers, namely the minister of religion, minister of internal affairs, and minister of education and culture with consecutive numbers; 6 of 1975, 037/U/1975 and 36 of 1975 concerning the upgrading of Madrasa education quality that resulted in curriculum changes. The Joint Decree is made to create the possibility to do joint activities across departments for increasing the Madrasa education quality so that the curriculum quality of general subjects or lessons in Madrasa can achieve the same targets that the public schools have. The decree has initiated the Madrasa to perform curriculum restructuring in Madrasa, 
which causes the weaken mastery in Islamic subjects since the Islamic subject percentage is also decreased (Fauzan \& Fata, 2019; Rohmah \& Arifin, 2017).

To lessen the negative impacts of the curriculum restructuring activities in Madrasa, some Madrasas have executed an innovation in curriculum development by utilizing Ma'had system. One of those Madrasas is MTsN 1 Malang. The Ma'had system implemented in this Madrasa can be seen from the way Ma'had al-madani was constructed in one location as it is integrated with the Madrasa. The curriculum implementation is carried out by integrating the Madrasa curriculum program and Ma'had education. To analyze the curriculum development innovation in MTsN I, the writer employs Hilda Taba's curriculum development theory comprising; (1) diagnosis of needs, (2) formulation of objectives, (3) selection of content, organization of content, (4) selection of learning experiences, (5) organization of learning experiences, and (6) determination of what to evaluate, the ways, and means of doing it (Print, 1992).

The innovative activities in the education curriculum development can be executed by focusing on three things. First, on the content, the implementation functions to maintain and transmit the knowledge, concepts, and existing values including both divinity and humanity values. Second, the focus is the process in which the implementation functions to construct situations and environments that support the development of students' needs and interests. The learning materials and sources are selected according to their interest and need. Meanwhile, teachers play the role as the psychologists who understand the students' needs and problems. Third, it is the convergence emphasizing on the content and process. The third group underlies the assumption that humans are social creatures that always need other human beings in their life, live with others, integrate and cooperate. By living together and cooperating, humans are able to live, develop and meet the daily needs and overcome various problems in life. The role of education is assisting the learners to be intelligent and capable of being responsible for the society's construction and development. Thus, education consists of actual problems the people encounter in real life. The education process or the learners' experiences are reflected through the study groups that prioritize cooperation among learners, between learners and educators, and other learning sources (Ali, 2008). Whereas, the curriculum development organization can be seen as; (1) curriculum for separable subjects, (2) curriculum for the similar subjects or branches of the same field of study, (3) core curriculum in which the curriculum materials are arranged based on students' problems and needs, and (4) integrative curriculum that bonds and centralizes the curriculum program and materials on certain topics and problems (Hamalik, 2006).

The integrative curriculum programs are accomplished through two levels. First, it involves the school principal and the vice principal who have a crucial role in forming, planning, monitoring, and evaluating the program. Second, it involves the 
class where all teachers are obliged to implement the curriculum program based on duty and expertise. On the other hand, the whole students' skills and characteristics are developed. They are also prepared to be graduates who can actively participate in the social life using certain approaches that boost cooperation between school and society (Ali, 2019a; Hamalik, 2006) . Therefore, the integrated curriculum program needs an integrative program supported by infrastructure and facilities, learning source unit, and integrated learning environment (Trianto, 2010). This program is essentially a learning system that provides a chance for students, both individually and in groups, to find, dig, and discover a concept and principle in active, holistic, and authentic ways.

For supporting the curriculum development innovation, literacy programs can be utilized to do innovative activity easily. In this era of sophisticated technology, students are required to possess literacy skills because they reflect one's ability in developing self-potential and skills for analyzing and understanding any information conveyed in digital media, communication tool, and social media. Literacy has some advantages such as optimizing the brain work, enriching insight and new information, enhancing the interpersonal ability, developing verbal ability, and training the thinking and analytical ability (Antoro, 2017; Wulanjani \& Anggraeni, 2019).

\section{[Q] Method}

This study uses a qualitative descriptive design. Primary data obtained through observation, interview, and documentation. The observation was carried out by looking at, observing, and visiting the site of teaching and learning activities, both the classroom and Ma'had al-madani in Malang to acquire a depiction of the integrated curriculum of Madrasa, Ma'had al-madani education, and students' literacy.

The interview was conducted by giving some inquiries regarding the chosen Madrasa curriculum program and Ma'had al-madani education, the learning strategy used, and the learning experience. The informants were selected by purposive sampling that included different criteria. Those are the head and vice head of the Madrasa, the Madrasa committee, the Ma'had head, the teachers and santri (students). The informations from informants then verified based on the focus. The documentation related to the Madrasa curriculum program and Ma'had educational program were analyzed according to the focus of the study.

The primary data, in form of the background depiction of the integrative program of Madrasa curriculum, Ma'had al-madani education, some programs, and literacy activities in determining the success of the integrative program, were anlayzed through data reduction, data display, and data verification. The data validity was checked through triangulation of sources and methods. 


\section{Result}

\section{The Background of the Integrative Program of Madrasa Curriculum and Ma'had Education}

School curriculum is a series of knowledge containing a number of programs and activity plans that will be used as the foundation and principle in carrying out the learning activities at school. The school curriculum implementation is always associated with the location and environment of the school, thus, there are various implementation models in accordance with the backgrounds that influence them. In compliance with this, the implementation of the integrated program of Madrasa curriculum and Ma'had al-madani education involved MTsN 1 Malang because this Madrasa is one of the schools in Malang that has Ma'had al-madani built in the same location. Besides, there are three aspects that encourage the decision maker to do an integration of Madrasa curriculum and Ma'had al-madani education at MTsN 1 Malang.

The first aspect contains the Madrasa vision and mission; the visions include being excelled in achievement, withstanding any competition, being polite, and having environmental awareness. Its missions are carrying out education effectively so that students can develop optimally, carrying out learning activities to develop students' active thinking ability, innovative action, and creativity in overcoming problems, to create and maintain a healthy environment and religious attitude so that students can truly apply and understand their religion, instill noble attitudes and apply the attitudes in daily life so that students can give exemplary actions to their friends and society, and improve tolerance, responsibility, independence, emotional intelligence and awareness towards the environment. To achieve those visions and missions effectively and efficiently, MTsN 1 develops facilities and infrastructure as well as the unit that supports the activity implementation, which takes place in the same location as the Madrasa's. The design of this integrated location is expected to make the planning and implementation of the Madrasa curriculum and Ma'had al-madani education program easy to be monitored and evaluated. This is in line with one of the goals of the Madrasa that is developing a curriculum issued by the government in creative, innovative, and integrative ways.

The second aspect is the vision and mission of Ma'had al-madani to create MTsN 1 Malang graduates who are excelled in faith, piety and technology, and science. This program is arranged by combining the general programs offered in traditional pesantren (salafiyah) and the programs offered in a high-achieving school. The types of Ma'had al-madani programs are taklim madrasy, taklim Ma'hady, ubudiyah assistance, tartil assistance and tahfidz, 2 foreign languages assistance (English and Arab), discipline and independence instilling, and art. The activites conducted in Ma'had almadani are oriented to support and strengthen the MTsN 1 curriculum programs and 
vision-mission. Some efforts performed by the head of the Madrasa to avoid "mislink and mismatch" are coordination meeting attended by the head of the Madrasa, the Madrasa committee, and the head of Ma'had al-madani. This event was conducted at night and took place in the Madrasa head office. The meeting was arranged by the head of the Madrasa committee.

Third, there is a tendency for the development of science, technology, and art studies (Science and Technology by linking knowledge of religion and science. On that basis, the programs in MM (Ma'had al Madani) of MTsN 1 Malang are directed so that students in MM are not only smart in religion but also understand adequate general science.

Programs in MM related to this third aspect include taklim Ma'hady that relate it to the study of religious books such as the hadith, fiqh, etc. Taklim madrasy related to general subjects in schools such as Mathematics, Science, foreign languages. There is also tahfidz Quran program as a forum of the development for students who are interested in memorizing Quran and students who have memorized it before entering MTsN 1 Malang. From the program, students are expected to be able to have an advantage in the field of religion and also general science so that they have competitiveness with alumni of other schools both in the scope of Madrasa and in public schools. The programs compiled by $\mathrm{MM}$ are different from other Islamic boarding house programs and also with the other Islamic junior high school. For example, MM students are given the opportunity to take part in an Olympic competition in the fields of science and also in the field of religion, as well as "yellow book" (classical Islamic books) reading contests, Arabic and English, Tahfidz Quran and public speaking. The various programs and activities show that the decision to run PKM integration with MM education is also influenced by the era of science and technology. Based on the three aspects that underlie the determination of integration, the goal of integrating the Madrasa curriculum program and MM education can be guaranteed to be realized in the environment of Madrasa.

\section{Activity and Literacy Factors in determining the Success of Integrating the Madrasa Curriculum Program and Ma'had Education}

The selection of learning activities that are potential in program integration activities can be seen in the relationship between the types of learning activities and literacy that have an influence in determining the successful implementation of integration and students' perceptions and information disclosure. Both aspects can be explained one by one as follows; The first aspect reveals the selection of the types of learning activities carried out in the MM environment that has a relationship with PKM.

Several types of activities chosen to be held at MM are grouped into two. First, it is Taklim Madrasy (TM) known as an activity that is oriented to assist students in 
deepening and developing knowledge in the fields of subjects that are considered as the national examination (UN) category and the final exam of the national standard of Madrasa (UAMBN) namely mathematics, natural sciences, English and Arabic.

The strategies used in the implementation of TM include giving assistance to students for UN and UAMBN subjects. Assistance for them is also performed when facing midterm test (PTS) and final test (PAS). The assistance is carried out with the aim that they understand the material that will be fully tested so that they do not experience difficulties in working on the test, become successful, and obtain high achievement.

TM activities held in MM can help the students to solve problems of learning difficulties about national exam and UAMBN material. This condition is supported by the existence of a boarding system in MM where all students and academic coaches stay in one location within 24 hours so that those who encounter difficulties in understanding the subject matter and examinations can ask for guidance directly to the coaches. In addition, non-material difficulties faced by students in the class can also get assistance to solve.

The strategy chosen in the implementation of TM in MM is influenced by the background of the establishment of MM, including to help the learning difficulties of MTsN 1 students outside the classroom in understanding and deepening Madrasa curriculum materials. Therefore, the establishment of MM was built after the founding of the Madrasa and also was an effort to facilitate the achievement of the objectives of the Madrasa curriculum so that all learning activities on TM are based on the curriculum used by MTsN 1 Malang, such as examining the exam materials and trial exams.

Another strategy chosen in compiling learning materials on TM in MM is through coordination meetings attended by the leaders, MM religion teachers, and teachers of MTsN 1 and in the form of guidance provided by Madrasa leaders and committees. Therefore, the strategy of implementing PKM integration activities and MM education in MTsN 1 Malang is different from Islamic boarding school in other schools.

The second aspect is Taklim Ma'hady al-Madani (TMM), an activity oriented to the deepening and development of the religious field. The learning resources used in religious studies are taken from the classic Islamic books commonly referred to as "yellow books", such as Aqidatul Awam, Safinatun Najah, Hidayatush Shibyan, fiqh of prayer, Ta'limul Muta'allim, Al-Arba'in An-Nawawiyah, Sulamut Taufiq, Nashaihul 'Ibad, and Taisirul Khallaq.

The strategy chosen in the TMM activities is a combination of strategies commonly used in traditional Islamic boarding school with the strategies used in religious studies on halaqoh in mosques and on campus. The use of this strategy can be seen, for example, when the Islamic teacher reads material in the book, it is also examined from 
the grammatical aspects (nahwu and shorof), and the meaning of the material being studied is always associated with the problems that occur in a daily life around the environment and the actual matters which is currently being discussed in the community. The strategy is directed to assist students in understanding curriculum materials in the Quran, hadith, morality, fiqh, Arabic language and their relevance to daily life.

The programs included in TMM category are (1) Ubudiyah Coaching directed to the formation of Islamic students' spiritualism. The coaching activities include; Fardhu prayers in congregation at Al-Fajr mosque, Tahajud (Midnight prayer) which are held twice a week in congregation at the mosque on Thursday night (where the Muslims are encouraged to do prayer) and Saturday night, sunnah fasting which is held on Monday and Thursday, sunnah fasting on Arafat and 'Asyuro day, and other sunnah fastings. (2) Activities of guidance to read al-quran in tartil and tahfidz. This activity aims to have the students have the skills and ability to read and memorize Quran correctly and fluently according to the recitation (Quran recitation procedures), and understand the meaning that exists in the verses of the Qur'an. The students are not required to participate in tahfidz program activities; it is provided only for those who have a unanimous interest and desire to memorize the Qur'an. Tartil and tahfidz programs are carried out before the Maghrib prayer. The method used in the activities of tartil and tahfidz al-quran is the system of memorizing rote and muroja'ah in front of the ustadz and ustadzah (male and female teachers) in charge. (3) Activities in mentoring Arabic and English language skills. This coaching activity is referred to as "shobahul lughoh".

Shobahul lughoh activities are oriented towards speaking and listening skills in two foreign languages. Shobahul lughoh is carried out in the morning by using the story and singing methods and role play. The use of methods such as the story method, implemented in a way, required students to tell stories using Arabic or English about certain themes and or retell what has been heard in accordance with the topic being told. The creativity and innovation methods used by coaches have an important role to manage and control the activities to be more interesting and not joyful, and (4) Selfdevelopment activities aimed at forming and instilling discipline and independence. This activity was carried out through organizational activities namely the Santri Ma'had (OSAMA) and organizations of arts through Banjari al-Madany sholawat group, the art of reading Quran (qiroah), public speaking, and Master Ceremony (MC). From these activities, the students became accustomed to understanding the integration of the Madrasa curriculum program and the education program held at al-Madani boarding school of MTSN 1 Malang and its relation to the vision and mission of Madrasa.

The second aspect is the level of literacy. The presence of high officials from the central Ministry of Religion, provincial and regional government, committee of Madrasa, tutors from outside the Madrasa, guests from overseas and out of town in the 
Madrasa environment and MM has a significant influence on the level of information literacy, digital and collaboration. This is indicated by the process of academic activities and self-development.

First, the students gain knowledge about the importance of ownership of technology and art science (IPTEKS) as well as faith and piety (IMTAQ) delivered by leaders from officials, community leaders who are members of the Madrasa committee, academics across fields of study so as to create enthusiasm and high motivation for them to learn and achieve even better achievements and to address problems in society related to technology and art science and IMTAQ.

Second, Madrasa, ustadz, and Islamic student leaders in MM MTsN 1 Malang are accustomed to serving guests and students from across the region and Madrasa that can open up openness and do not discriminate others.

Third, acceptance of differences in socio-economic status, habits, difference of regional and ethnic origin in the Islamic boarding school environments in MM of MTsN 1 can gather a shared attitude, collaboration, and information sharing related to school work.

Fourth aspect is creating openness in discussions, sharing information on digital learning resources, and group working related to work from school or assignments from Islamic boarding school. These four aspects reflect the level of information literacy, digital, and collaboration in the integration of PKM and the education in MM of MTsN 1 Malang.

\section{i jiscussion}

Ma'had (pesantren) was establised out of the experience of the surrounding community because Ma'had has a strong relationship with its environmental community and is able to survive until now. Besides, Ma'had also can adjust and readjust the meaning of Indonesian authenticity (Ali, 2008, 2019b). Whereas, Madrasa is one form of formal Islamic education institutions in Indonesia. It was established by the government as a form of attention to meet the needs of the community for formal education that emphasizes religious-based subjects. In line with the changing times, government policies and community needs, Madrasas also develop curriculum and learning programs. In the context of MTsN 1 Malang, curriculum programs in Ma'had and Madrasa are integrated in an effort to realize the Madrasa vision and mission. The integration carried out in Madrasa is not only about the curriculum program but also the institutional and infrastructure facilities. In this context, the implementation of integration in Madrasa in Malang has involved four categories as offered by Mahzar, namely the conceptual, institutional, operational, and architectural levels (Mahzar, 2005) 
The integration of the Madrasa curriculum program and MM education executed in Madrasas in Malang was developed in three forms namely pedagogical, socialpsychological, and social-cultural (Kondrakova, 2018). First, the form of pedagogic organization in the development of curriculum programs in Madrasa and Ma'had is accomplished by using an integrated curriculum, where curriculum and education programs exist in classrooms, Ma'had, mosques, and self-development program run in an integrated manner. Second, social-psychological forms, namely teaching and learning activities and coaching programs related to the curriculum of Madrasa and Ma'had, are carried out in school classrooms, Ma'had's dormitories, mosques and halls. Third, in the form of socio-cultural information literacy activities, digital, and collaborative manifested in the form of lectures, accompaniment, daily communication and interaction in Ma'had dormitory with guests, committees, academic tutors from outside the Madrasa, such as organizing religious activities on Islamic holidays, contests, performing arts, and social services on the day of Iedul adha in the village community and schools in rural areas.

In implementing the integration of PKM and MM education in Madrasa, there are several principles used such as; first, the curriculum program is based on the potential, development and conditions of students to master competencies that are useful for themselves. Students must get a good education quality and have the opportunity to express themselves freely, dynamically and pleasantly.

Second, the curriculum program is organized on the basis that learning is oriented to increase faith and piety to God Almighty, to understand and appreciate, and be able to practice and benefit humanity.

Third, the curriculum program allows students to obtain services to the improvement, enrichment, and/or acceleration in accordance with their potential, stages of development, and conditions while still paying attention to the integration of personal dimensions of God, individual, social, and moral.

Fourth, the curriculum program is held in an atmosphere of student and educator relations that accept and respect each other, are familiar, open, and warm, with the principles of Tut Wuri Handayani, Ing Madia Mangun Karsa, Ing Ngarsa Sung Tulada (giving power and strength in the back, building enthusiasm and initiative in the middle, giving the guidance and example in front).

Fifth, the curriculum is implemented using a multi-strategic and multimedia approach, adequate learning resources and technology, and utilizes the surrounding environment as a source of learning.

Sixth, the curriculum program implemented includes subject competencies, local content and self-development, held in balance, interrelation, and sustainability that is suitable and appropriate (Ali, 2008). 
Based on the ideas, the integration of PKM and MM education in Madrasa becomes urgent and strategic to produce strong human resources in Science and Technology and IMTAQ fields because the competencies of Islamic and Ma'had graduates have quite obvious differences when they graduate. The difference is apparent, not only when facing the world of work, but also their competence. Ma'had graduates are stronger in fields related to social and religion, while Madrasa graduates are stronger in fields related to Science (Yusuf, 2017).

The urgency of the integration of the program is also related to the background of the establishment of Ma'had and Madrasa based on religious values derived from the Quran and the yellow books, the principles of the leaders and the values of the results of interaction with socio-cultural reality and developing politics and the interactions with the international world (Dahlan, 2016).

In addition, the involvement of Madrasa leaders, teachers and committees in Madrasa with students in PKM and Ma'had education outside the classroom informally can at least give two new experiences. First, the presence of students in the dormitory and outside the Madrasa class can provide new experiences and comparisons and even enrich students' insights related to the relationship between curriculum material taught in class and facts in the field. Second, the experiences of participating in curriculum programs in Islamic classes, educational programs in the Ma'had dormintory, and activities outside the Madrasa have provided new values that can be used as a reference to shape students' character and personality better. This way, Madrasa students will gain different experiences that enable them to put themselves in relations between students, groups, and ethnic groups more openly. The dormitory, as a supporting system for the integrative program activities in Madrasa in Malang can also increase information and digital literacy and collaboration among students and teachers. Thus, the integration of curriculum programs that integrates content, process and learning experiences can be categorized in the flow of social reconstruction.

\section{首 Conclusion}

The activity of integrating the Madrasa curriculum program and Ma'had education was influenced by the initial objective of establishing Madrasa and government policies in the field of Madrasa education. The determination of the Madrasa integrated curriculum program is a solution to overcome the negative impact of the curriculum restructuring program. The Ma'had boarding system which is integrated with Madrasa can increase the literacy of students and teachers, and determine the successful implementation of the integration of the Madrasa curriculum program and Ma'had education. This also emphasizes the need for innovation in the development of integrative Madrasa curriculum programs. 


\section{Bibliography}

Abdullah, A. (2013). Perkembangan pesantren dan madrasah di Indonesia dari masa kolonial sampai orde baru. Paramita, 23(2), 193-207.

Ali, N. (2008). Manajemen pengembangan kurikulum sekolah menengah kejuruan di lingkunan pesantren. PPS Universitas Negeri Malang.

Ali, N. (2019a). Integrative curriculum of religion and science at special pesantren for univerity students. ULUL ALBAB Jurnal Studi Islam, 20(1), 95-122. https://doi.org/10.18860/ua.v20i1.6353

Ali, N. (2019b). Pengorganisasian kurikulum dan pembelajaran pada sekolah kejuruan di lingkungan pesantren. Jurnal Manajemen Pendidikan Islam, 4(1), 48-59.

Antoro, B. (2017). Gerakan literasi sekolah dari pucuk hingga akar: Sebuah refleksiitle. Jakarta: Kemendikbud.

Dahlan, M. Z. (2016). Internalisasi pendidikan karakter di Sekolah. Jurnal Lisan Al-Hal, $7(1), 155-172$.

Fakhruddin, U., \& Saepudin, D. (2018). Integrasi dalam sistem pembelajaran di pesantren. Ta'dibuna: Jurnal Pendidikan Islam, 7(1), 94-113. https:/ / doi.org/10.32832/tadibuna.v7i1.1355

Fauzan, P. I., \& Fata, A. K. (2019). Jaringan pesantren di Jawa barat tahun 1800-1945: Critical review atas disertasi “Jaringan pesantren di priangan 1800-1945" Karya Ading Kusdiana. Jurnal Lektur Keagamaan, 17(1), 139-168. https://doi.org/10.31291/jlk.v17i1.602

Hamalik, O. (2006). Manajemen pengembangan kurikulum (cet. perta). Bandung: Remaja Rosdakarya.

Hasri. (2014). Madrasah sebagai lembaga pendidikan Islam. Al-Khwarizmi, II(I), 69-84.

Jamasri. (2018). Metode penanaman nilai sosial pada santri di pondok pesantren salafiyah dan implementasinya dalam legiatan masyarakat pulutan lor rw 02 kecamatan sidorejo kota salatiga tahun 2018. PKn Progresif, 13(2), 1-10. https:/ / doi.org/10.1542/peds.2006-2099

Karimah, U. (2018). Pondok pesantren dan pendidikan : Relevansinya dalam tujuan pendidikan. MISYKAT: Jurnal Ilmu-Ilmu Al-Quran, Hadist, Syari'ah Dan Tarbiyah, 3(1), 137-154. https:// doi.org/10.33511/misykat.v3i1.50

Kemenag. (2019). Pedomn implementasi integrasi ilmu di perguruan tinggi keagmaan islam( PTKI ) Direktorat Pendidikan Tinggi Keagamaan Islam Dirjen Pendidikan Islam Kementerian Agama Republik Indonesia. 
Kondrakova, E. D. (2018). The program me of Pyatigorsk state university on counter extremism activities on the territory of the educational organization and student dormitories. International Journal of Engineering $\mathcal{E}$ Technology, 7(2), 56-61.

Mahzar, A. (2005). Integrasi sains dan agama: model dan metodologi. In Integrasi ilmu dan agama: Interpretasi dan aksi (pp. 92-100). Bandung: Mizan.

Mukhibat, M. (2016). Meneguhkan kembali budaya pesantren dalam merajut lokalitas, nasionalitas, dan globalitas. KARSA: Jurnal Sosial Dan Budaya Keislaman, 23(2), 177192. https:// doi.org/10.19105/karsa.v23i2.717

Nasir, M. (2015). Kurikulum madrasah: Studi perbandingan madrasah di Asia. Nadwa, 9(2), 145-166. https:/ / doi.org/10.21580/nw.2015.9.2.524

Print, M. (1992). Curriculum development and design (Fourth, Ed.). North Sudney: Allen \& Unwin.

Rohmah, M. R., \& Arifin, Z. (2017). Eksistensi dan pengembangan kurikulum madrasah aliyah program keagamaan (MAPK) MAN 1 Surakarta. Jurnal Pendidikan Madrasah, 2(2), 369-384. https:/ / doi.org/10.14421/jpm.2017.22-11

Saifuddin, A. (2015). Eksistensi kurikulum pesantren dan kebijakan pendidikan. Jurnal Pendidikan Agama Islam (Journal of Islamic Education Studies), 3(1), 207-234. https://doi.org/10.15642/ pai.2015.3.1.207-234

Styaningsih, R. (2016). Kontinuitas pesantren dan madrasah di Indonesia. At Ta'Dib, 11(1), 167-183. https:/ / doi.org/10.21111/at-tadib.v11i1.651

Trianto. (2010). Model pembelajaran terpadu. Surabaya: Bumi Aksara.

Wulanjani, A. N., \& Anggraeni, C. W. (2019). Meningkatkan minat membaca melalui gerakan literasi membaca bagi siswa sekolah dasar. Proceeding of Biology Education, 3(1), 26-31. https://doi.org/10.21009/pbe.3-1.4

Yusuf, M. (2017). Dinamika integrasi dan sekolah dalam pendidikan kontemporer di Indonesia. Al-Murabbi, 3(2), 178-191. https:/ / doi.org/10.1021/la048177k

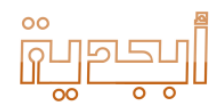

